\title{
Veni, Vidi, da Vinci
}

Citation for published version (APA):

Delhaas, T. (2010). Veni, Vidi, da Vinci. Maastricht University. https://doi.org/10.26481/spe.20101210td

\section{Document status and date:}

Published: 10/12/2010

DOI:

$10.26481 /$ spe.20101210td

Document Version:

Publisher's PDF, also known as Version of record

\section{Please check the document version of this publication:}

- A submitted manuscript is the version of the article upon submission and before peer-review. There can be important differences between the submitted version and the official published version of record.

People interested in the research are advised to contact the author for the final version of the publication, or visit the DOI to the publisher's website.

- The final author version and the galley proof are versions of the publication after peer review.

- The final published version features the final layout of the paper including the volume, issue and page numbers.

Link to publication

\footnotetext{
General rights rights.

- You may freely distribute the URL identifying the publication in the public portal. please follow below link for the End User Agreement:

www.umlib.nl/taverne-license

Take down policy

If you believe that this document breaches copyright please contact us at:

repository@maastrichtuniversity.nl

providing details and we will investigate your claim.
}

Copyright and moral rights for the publications made accessible in the public portal are retained by the authors and/or other copyright owners and it is a condition of accessing publications that users recognise and abide by the legal requirements associated with these

- Users may download and print one copy of any publication from the public portal for the purpose of private study or research.

- You may not further distribute the material or use it for any profit-making activity or commercial gain

If the publication is distributed under the terms of Article $25 \mathrm{fa}$ of the Dutch Copyright Act, indicated by the "Taverne" license above, 
Veni, Vidi, da Vinci 


\section{Colofon}

Ontwerp en print: Océ Business Services, Maastricht Afbeelding omslag: Juan Heurter, Acryl op papier (2010)

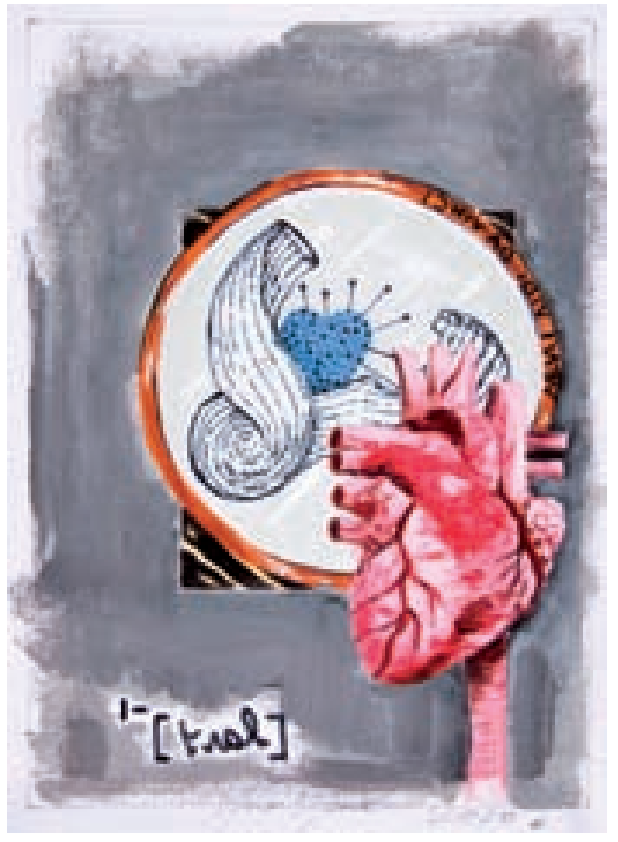

ISBN: 978-90-5968-1358-1

NUR: 954

Alle rechten voorbehouden. Niets uit deze uitgave mag worden verveelvoudigd, opgeslagen in een geautomatiseerd gegevensbestand of openbaar gemaakt worden, zonder voorafgaande schriftelijke toestemming van de auteur of uitgever. 


\section{Veni, Vidi, da Vinci}

\section{Rede}

uitgesproken bij de aanvaarding van het ambt van hoogleraar Biomedische Technologie aan de Faculty of Health, Medicine and Life Sciences van de Universiteit Maastricht

Maastricht, 10 december 2010

Prof. dr. Tammo Delhaas 
4 Prof. dr. Tammo Delhaas 
Mijnheer de Rector Magnificus, Decaan van de Faculty of Health, Medicine and Life Sciences, Gewaardeerde collega's, Lieve familie en vrienden, Geachte toehoorders,

Een fuga is een muziekvorm waarin meerstemmigheid en gevarieerde herhaling een hoofdrol spelen. Het belangrijkste thema, ook wel subject genoemd, reist door alle stemmen. Hierbij worden diverse toonsoorten en themabehandelingen gebruikt. Om te weten wat het thema is, wordt dit als eerste eenstemmig gespeeld in de expositie, waarin, net als in een klassiek toneelstuk, uit de doeken gedaan wordt waar het muziekstuk over handelt. Nadat het thema ten gehore is gebracht komt het muzikale antwoord, waarbij de tweede stem het thema weergeeft in een andere toonsoort. In de eerste stem kan dan vervolgens weer nieuw materiaal aangeboden worden, het zogenaamde contrasubject. Dit proces herhaalt zich voor de volgende stemmen.

Net als een toneelstuk, kent ook een fuga meerdere bedrijven, die doorgaans onderbroken worden door korte divertimenti waarin op het materiaal van de thema's wordt gevarieerd. Elk bedrijf binnen de fuga kenmerkt zich door een specifiek gebruik van bepaalde toonsoorten en themabehandelingen.

In deze rede wil ik graag een fuga maken op het thema spiegeling. Omdat ik alleen aan het woord ben, kan ik helaas niet meerdere stemmen tegelijk laten klinken. Wel zal ik gebruik maken van vele, het contrapunt betreffende, compositorische technieken.

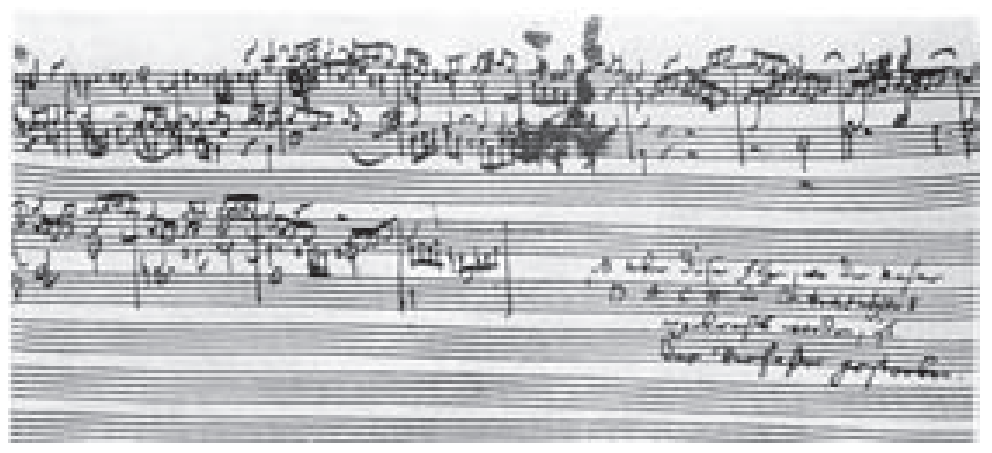

Figuur 1 Het onvoltooide Contrapunt XIV uit de Kunst der Fuge (BWV 1080) met de aantekening van C.Ph.E. Bach. 


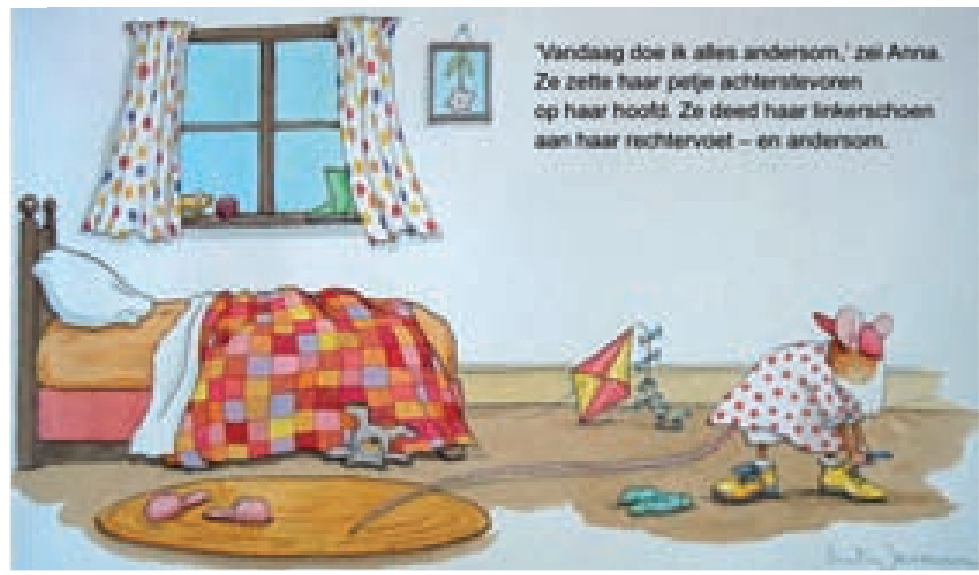

Figuur 2 'Vandaag doe ik alles andersom', zei Anna. (๔ Anita Jeram)

Voor de expositie neem ik $u$ mee naar het boekje met tekst en illustraties van Anita Jeram, dat door de Stichting Collectieve Propaganda van het Nederlandse boek werd uitgegeven ter gelegenheid van de Kinderboekenweek 2001. Het boekje heet 'Muisje Andersom' en ik wil het u nu gaan voorlezen:

'Vandaag doe ik alles andersom,' zei Anna.

Ze zette haar petje achterstevoren op haar hoofd.

Ze deed haar linkerschoen aan haar rechtervoet- en andersom.

'Anna, ben je al op?' riep mamma.

'Nee!' zei Anna.

Toen mamma vroeg:

'Wat wil je hebben voor je ontbijt?'

zei Anna: 'Patat met appelmoes.'

Ze gingen boodschappen doen.

Het regende dat het goot.

'Kom toch onder de paraplu,' zei mamma. 
'Nee,' zei Anna.

Ze holde door de plassen en werd kleddernat.

De hele dag deed Anna alles andersom.

Ze fietste achterstevoren.

Ze liep op haar handen door de tuin.

'Wat heb je toch?' vroeg mamma.

En Anna zei: 'Ik ben Muisje Andersom.'

'Zozo,' zei mamma.

Toen mamma Anna die avond naar bed bracht, Stopte ze haar ondersteboven in.

Ze trok de gordijnen open

Deed het licht aan

Gaf Anna een zoen op haar tenen en zei:

'Word maar lekker wakker!'

Anna moest vreselijk lachen:

'Haha! Mamma Andersom!'

Mamma knuffelde Anna.

'Vind je mij lief, Muisje Andersom?'

'NEE!' riep Anna.

En ze gaf haar moeder een dikke zoen.

Dit verhaal vertelt op alleraardigste wijze wat er gebeurt wanneer we spiegelen, en welke problemen je dan krijgt ten aanzien van links-rechts verwisseling, omdraaien van boven en onder, en de betekenis van taal. 


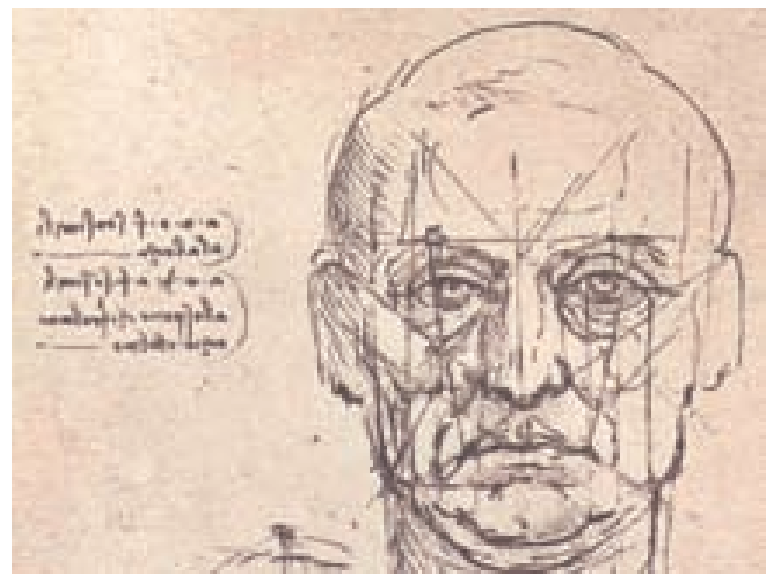

Figuur 3 Portretstudie door Leonardo da Vinci, ca. 1489/149o (pen en inkt over metaalstift op geel geprepareerd papier, 140 × 277 mm, Turijn, Bibliotheca Reale, inv. 15574 D.C. recto).

Voor de tweede stem moeten we kijken naar de afbeelding van een door Leonardo da Vinci getekend gezicht. De afbeelding gaat gepaard met onbegrijpelijke tekst. Tekst die op zo'n manier is geschreven dat u er kop noch staart van kunt maken. $U$ heeft nu dezelfde ervaring als die zo mooi beschreven is door Charles Dodgson, een deken in de Anglicaanse kerk in de tweede helft van de $19^{\mathrm{e}}$ eeuw. Als zoveel geestelijken in die tijd begaf hij zich niet alleen op het vlak van de theologie, maar had hij ook Wiskunde en Logica gestudeerd. Onder zijn pseudoniem Lewis Caroll heeft deze man in 1865 het boek 'Alice's adventures in wonderland' geschreven. In dit boek speelt de wiskundige in hem met zin en onzin, tegenstellingen, en wiskundige begrippen als limiet.

In het vervolgboek, 'Through the looking-glass, and what Alice found there', in het Nederlands 'Door de spiegel' geheten, speelt Alice in de keuken met haar witte en met haar zwarte kat. Plotseling ziet ze een spiegel op de schoorsteenmantel en vraagt ze zich af hoe de wereld aan de andere kant van de spiegel zou zijn. Ze klimt op een stoel en morrelt wat aan de spiegel. Tot haar verbazing bemerkt ze dat ze door de spiegel heen kan gaan en in een alternatieve wereld terecht komt: spiegelland. In deze gespiegelde versie van haar eigen huis stuit ze op een boek met onleesbare poëzie, zoals in de tekening van Leonardo. 

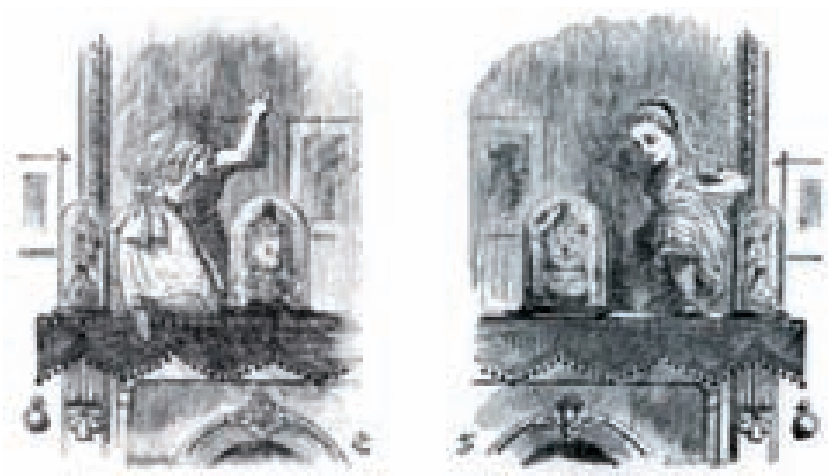

Figuur 4 Illustraties uit 'Through the looking-glass, and what Alice found there' door Lewis Caroll.

Gelukkig is Alice slim genoeg om te realiseren dat als een spiegelbeeld nog eens wordt gespiegeld, het origineel weer tevoorschijn komt. Ze wordt dus enthousiast, juicht dat het spiegelpoëzie is en houdt het boek voor de spiegel. En jawel hoor, de onbegrijpelijke tekst wordt ineens leesbaar. Opmerkelijk voor ons is, dat, terwijl we bij de gespiegelde Nederlandse tekst nog wel enigszins een idee hebben wat er zou kunnen staan, we ons bij de Engelse tekst met zijn voor ons onbegrijpelijke neologismen, bijna totaal geen idee kunnen vormen wat er in de gespiegelde versie staat.

\section{- Whownddal Jahberwosky.}

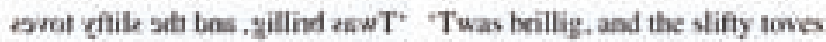
solew sto ai sldmig bne reg bid Did gyre and gimble in the wabe:

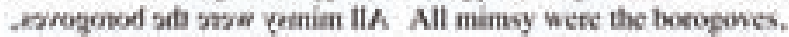
sodngtuo eflin saxom sith bih. And the mome raths outgrabe.

\section{Jeswalsod Kocterwaal.

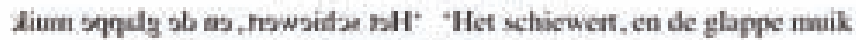

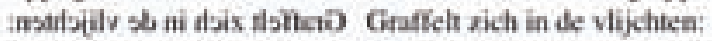

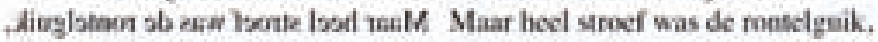 astgind uslsow grate na En strave woelen krijgtea.}

Figuur 5 De spiegelpoëzie die Alice aantrof (boven het originele 'Jabberwocky' en onder de vertaling 'Koeterwaal', gemaakt door Nicolaas Matsier in 1994). 
Laten we nu de tekening van Leonardo weer eens nader bekijken, waarbij we ons in $1^{\mathrm{e}}$ instantie concentreren op de tekst en ik daarom maar even de tekening van het hoofd schematisch weer zal geven. Wat opvalt na de spiegeling is dat het schrift inderdaad leesbaar wordt, zij het dat het een voor ons niet al te gebruikelijk lettertype is en er nog wel wat eigenaardigheden qua leestekens aanwezig zijn. Wat tevens opvalt is dat er met het hoofd niets gebeurd is. Dat ziet er na de spiegeling nog net zo uit. Deze bewerking maakt direct duidelijk dat bij spiegeling links en rechts verwisseld worden, maar ook dat het $u$ niet zal opvallen of $u$ naar een spiegelbeeld of naar het echte beeld kijkt, wanneer er geen asymmetrische voorwerpen op het plaatje voorkomen.

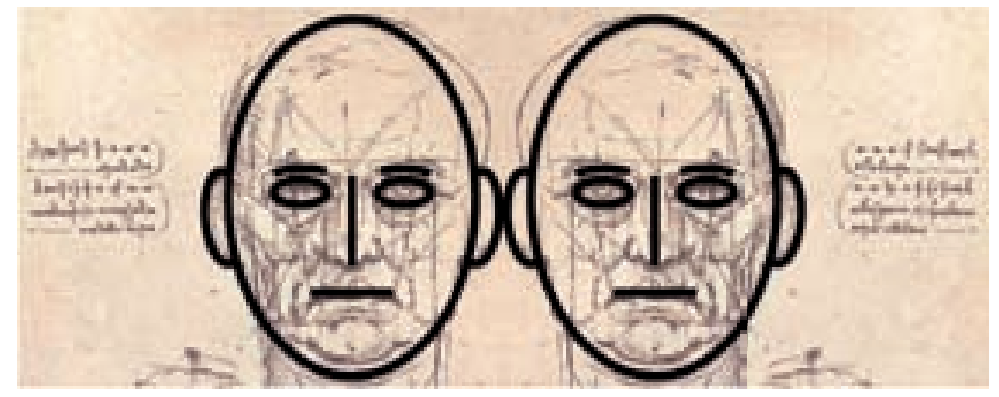

Figuur 6 Portretstudie door Leonardo da Vinci met gesuperponeerd een schematische weergave van het gezicht (links origineel, rechts gespiegeld).

Alvorens de andere stemmen te introduceren, wil ik eerst een augmentatie, een proportionele vergroting van de notenwaarden, c.q. het thema, maken. Dat wil zeggen dat ik eerst meer in detail op spiegeling in zal gaan.

Want wat is er gebeurd bij de spiegeling van de tekst van da Vinci: links en rechts zijn wel verwisseld, of, juister gezegd, voor en achter, maar onder en boven niet! Misschien zult u nu zeggen dat je onder en boven wel kunt verwisselen door de spiegel in het horizontale vlak te houden, zoals we dat uit de natuur kennen van spiegelingen op wateroppervlaktes. Bij dit soort spiegelingen treedt er weer geen verwisseling van links en rechts op, maar is het wel heel duidelijk dat bij spiegeling voor en achter worden verwisseld. In deel 1 van het door mij hooglijk gewaardeerde 
boek 'De natuurkunde van 't vrije veld' door prof. dr. M. Minnaert, gaat de auteur tientallen bladzijden lang in op de fysische aspecten van spiegeling in wateroppervlakten, waarbij hij duidelijk maakt dat in de natuur, omdat de spiegel zich zelden verticaal voor onze ogen bevindt, er altijd grote perceptuele verschillen zijn tussen beeld en spiegelbeeld.

Maar laten we ons hier nu beperken tot recht voor onze ogen verticaal opgestelde spiegels. Stel dat ik het volgende getekende hartje voor een spiegel hou, dan bent $u$ niet in staat het beeld en het spiegelbeeld van elkaar te onderscheiden. Dat komt omdat het een symmetrisch getekend hartje betreft. In algemenere termen: elk 2-dimensionaal figuur met op zijn minst één symmetrieas, hier aangegeven met de gestippelde lijn, kan over zijn spiegelbeeld heen gelegd worden, zonder dat er speciale maatregelen als rotatie in een hogere dimensie voor nodig zijn. Om dit duidelijk te maken geef ik $u$ een aantal voorbeelden waarin we gaan kijken of we symmetrieassen kunnen vinden. Hebben het hartje, de driehoek en de vijfhoek slechts één symmetrieas, het vierkant en het kruis hebben er 4 , de cirkel oneindig veel, en de trapezoïde en de spiraal hebben er geen één.
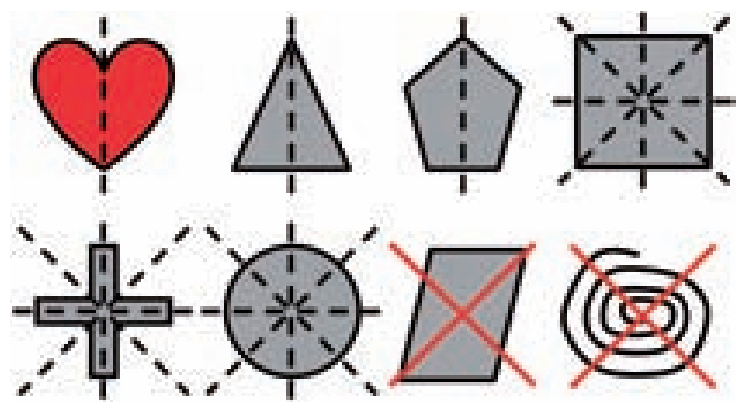

Figuur 7 Tweedimensionale figuren hebben geen, één, of meerdere symmetrieassen.

We komen nu aan bij spiegeling van 3-dimensionale voorwerpen. Ook deze voorwerpen kunnen verdeeld worden in spiegelsymmetrische voorwerpen en zij die asymmetrisch zijn. Het is duidelijk dat de cilinder, de kubus en de stoel symmetrische voorwerpen zijn: zij kunnen over hun spiegelbeeld heen gelegd worden omdat zij 1 of meerdere symmetrievlakken hebben. 

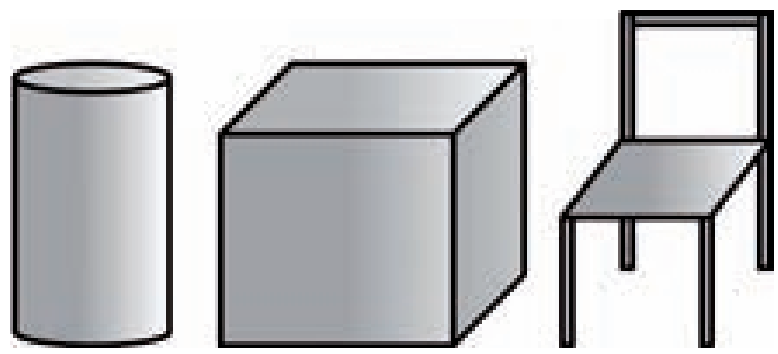

Figuur 8 Driedimensionale voorwerpen met minimaal één symmetrieas.

Asymmetrische figuren zijn voorwerpen die, hoe ze ook bewogen worden, nooit kunnen samenvallen met hun spiegelbeeld. Een voorbeeld hiervan is de helixstructuur van de kurkentrekker, de 3-dimensionale tegenhanger van de spiraal. Het mooiste voorbeeld daarvan kwam ik tegen in Venetië: de aanlegpaal voor gondels. Deze paal heeft als paal natuurlijk oneindig veel symmetrievlakken in de lengterichting, maar door de toevoeging van de helixschildering aan de buitenzijde heeft het als geheel geen symmetrieas meer.

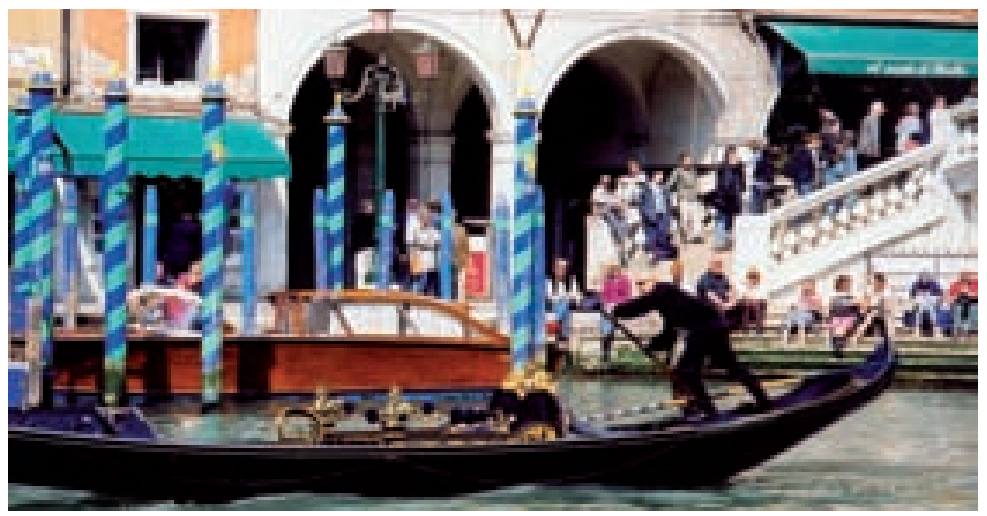

Figuur 9 De aanlegpaal voor gondels is een typisch voorbeeld van een asymmetrisch 3-dimensionaal voorwerp. 
Elke asymmetrische figuur heeft een spiegelbeeld dat precies gelijk is aan het originele beeld, behalve dan dat het de andere kant op gaat. Twee asymmetrische figuren die het spiegelbeeld van elkaar zijn worden 'enantiomorfen' genoemd. Enantiomorfen worden vaak linksof rechtshandig genoemd vanwege het meest bekende voorbeeld van enantiomorfen, onze handen: ze lijken precies op elkaar, maar toch is het direct duidelijk wanneer je met een linker of met een rechter hand van doen hebt. Zo wordt de helix van een kurkentrekker, schroef of bout een rechtshandige helix genoemd wanneer het desbetreffende voorwerp dieper in de kurk, hout, plug, of moer gaat wanneer het in de richting van de klok wordt gedraaid. Dat genoemde gebruiksvoorwerpen met deze richting van de helix zijn uitgevoerd, komt waarschijnlijk omdat onze maatschappij overwegend rechtshandig is en we de grootste kracht kunnen uitoefenen met onze rechter hand bij het draaien in de richting van de klok, het zogenaamde supineren. Hebben alle schroeven en bouten een rechtshandige helix? Er zijn uitzonderingen, maar die plaatsen ons, omdat ze zo uitzonderlijk zijn, telkens weer voor problemen. Ik noem de aansluiting van de drukverdeler op een gasfles. Altijd weer moet je nadenken welke kant je op moet draaien om hem los te krijgen. Vergeten moet je het ezelsbruggetje: linksom met de L van los. Dat geldt ook voor die voor de Nederlander zo bekende enantiomorf 'de fietstrapper'. De linker trapper heeft een linkshandige draad omdat deze trapper anders door de bewegingsrichting weer zou losdraaien.

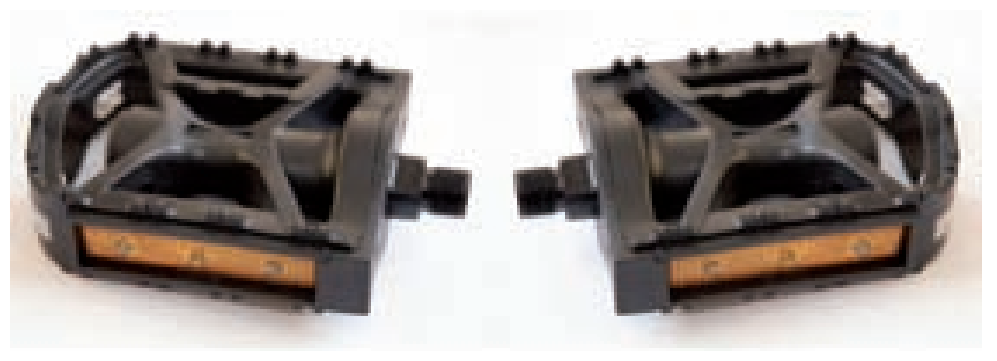

Figuur 10 Enantiomorfen uit het dagelijks leven. 
We keren weer terug naar de tekening door da Vinci van het gelaat van een man, waarbij mijn schematische tekening verwijderd is. De originele tekening is een mooi voorbeeld van de benaderingswijze van de kunst, natuur en wetenschap door Leonardo da Vinci, die wel de meest onverbiddelijk nieuwsgierige mens in de geschiedenis is genoemd.

Leonardo da Vinci, geboren op 15 april 1452 te Vinci (in de buurt van Florence) en overleden op 2 mei 1519 in Amboise op het chateau Cloux, had een holistische en ecologische zienswijze die onder andere mooi tot uiting komt wanneer hij op één en dezelfde pagina in zijn schetsboeken zowel architectuur als menselijke anatomie weergeeft, of turbulent water en lucht, draaikolken, het golven van haar en de patronen van groeiend gras. De kern van zijn onderzoekingen was een verkennen van patronen en het onderling verbinden van natuurverschijnselen uit een enorme verscheidenheid aan vakgebieden. Leonardo ontwierp een nieuwe empirische benadering van de wetenschap, gebaseerd op logisch denken, een systematische observatie van de natuur en een aantal wiskundige formuleringen: de voornaamste kenmerken van wat vandaag de dag de wetenschappelijke methode wordt genoemd. Deze benaderingswijze wordt door hemzelf kernachtig als volgt samengevat: 'Maar voor ik verder ga, zal ik eerst enkele experimenten doen, want het is mijn bedoeling eerst de praktijk op te schrijven, en dan te beredeneren waarom deze zo wel moet zijn. Dit is de enige ware regel die degenen die zich in de effecten van de natuur verdiepen, dienen te volgen.' Einde citaat. (Leonardo da Vinci, circa 1513). Da Vinci verbond waarnemingen en ideeën uit verschillende disciplines met elkaar: spieren en botten zag hij met de ogen van een ingenieur als een verzameling van hefbomen en koppelingen. Bij wervelingen in water en lucht moest hij direct denken aan eigenschappen van geluid en muziek en ging dan vervolgens ook bv. het ontwerp van muziekinstrumenten bestuderen. Volgens da Vinci hadden we dringend behoefte aan een wetenschap die de eenheid van alle leven erkent en respecteert, die de fundamentele onderlinge afhankelijkheid van alle natuurlijke verschijnselen inziet en ons met de levende aarde verbindt. Dit interdisciplinair perspectief was nodig om het leven in volle glorie te begrijpen en te waarderen. Leonardo da Vinci houdt ons een spiegel voor, en, terwijl dat normaal een vertekening van het beeld geeft met verwisseling van links en rechts, leidt dat in dit geval tot een waarneming van én omgang met de werkelijkheid zoals die heden ten dage gepropageerd wordt. Leonardo da Vinci was een systeemdenker, een systeembioloog 'avant la lettre'. 
Zijn wetenschappelijk werk hield Leonardo, in tegenstelling tot zijn kunst, echter verborgen. Als een antieke versie van $\mathrm{O}$ uit de Bond films, had Leonardo een dusdanige constructie in zijn werkkamer gemaakt, dat zijn werktafel via allerlei katrollen en tegengewichten door de vloer naar een onderliggende verdieping kon zakken, om het zo aan nieuwsgierige ogen te kunnen onttrekken. De vraag of hij in spiegelbeeld, dat wil zeggen van rechts naar links, schreef omdat hij linkshandig was, of omdat het ook de toegang tot zijn werk bemoeilijkte, zullen we nooit kunnen beantwoorden. Fritjof Capra noemt in zijn boek 'De wetenschap van Leonardo da Vinci' als voornaamste reden dat Leonardo zijn wetenschappelijke kennis niet met anderen deelde, dat hij deze kennis beschouwde als zijn intellectuele kapitaal. Zijn kennis vormde de basis van zijn technische vaardigheden, die op hun beurt weer de voornaamste bron van vast inkomen waren. Leonardo ging dus niet alleen in de uitvoering van zijn wetenschap zeer modern te werk, ook de geheimhouding van zijn wetenschappelijk werk lijkt zeer modern als je dat vergelijkt met de huidige gang van zaken waarbij onderzoeksresultaten soms eerst gepatenteerd, en dan pas gepubliceerd worden. Bij Leonardo heeft die geheimhouding er echter toe geleid dat zijn wetenschappelijk werk tot ver in de 18e eeuw bijna onopgemerkt bleef. Mijns inziens kan de wat-als vraag 'Stel dat het werk van Leonardo da Vinci tijdig bekend zou zijn geworden, zou dan de geboorte van de klassieke natuurwetenschap met anderhalve eeuw vervroegd kunnen zijn?' niet beantwoord worden, omdat dit een niet uit te voeren experiment is. Waar Fritjof Capra zeer sterk de neiging is toegedaan deze vraag positief te beantwoorden, is Eduard Jan Dijksterhuis, hoogleraar in de geschiedenis der exacte wetenschappen aan de universiteiten van Leiden en Utrecht, in zijn in 1950 verschenen boek 'De mechanisering van het wereldbeeld' zeer terughoudend en schrijft hij aanvankelijk redelijk negatief over het werk van Leonardo da Vinci. Ik citeer: 'Het is nauwelijks aannemelijk te achten, dat deze chaotische verzameling van notities, waarin flitsen van genialiteit afgewisseld worden door heel gewone excerpten uit alom bekende werken, in handen van anderen aan het algemene peil der wetenschapsbeoefening meer ten goede zouden zijn gekomen dan nu de auteur ze zijn gehele leven onder zijn berusting heeft gehouden en zij eerst na zijn dood toch nog bekend zijn geworden.' Einde citaat. Maar verderop steekt Dijksterhuis toch weer de loftrompet over de integrale wijze waarop Leonardo als schilder, beeldhouwer, maar vooral ook altijd als ingenieur een fenomeen benadert. 
Ik vraag weer uw aandacht voor de tekening door Leonardo van een gezicht met alle wetmatigheden qua verhoudingen. Wanneer we deze wetmatigheden voor absolute waarheden houden, gedragen we ons een beetje als ingenieurs die het contact met de werkelijkheid hebben verloren. We maken mooie sommetjes, komen met prachtige formules op de proppen, maar vergeten dat de natuur zich weliswaar aan basisregels houdt, maar dat er een grote spreiding is waar men altijd rekening mee dient te houden. Het grote verschil tussen natuur en techniek, tussen fysiologische experimenten en het uitvoeren van metingen in proefopstellingen, is dat in de natuur de herhaalbaarheid van een experiment bijna nooit zo groot is als in de techniek. Dit geeft aan dat de complexe levende materie, door de onderlinge verbondenheid, vrij brede veiligheidsmarges heeft. Houd je geen rekening met deze natuurlijke spreiding, dan kun je in problemen komen. Dit laatste wordt mooi geïllustreerd aan de hand van een bericht uit de Volkskrant van 5 november jongstleden, waarin gemeld wordt dat niet elke Nederlander een gezicht heeft dat voldoet aan de voorschriften voor de portretfoto die in het paspoort dient te komen. Volgens de voorschriften heeft een portretfoto voor een Nederlands paspoort vaste afmetingen van de foto zelf, én zowel een minimale en maximale hoofdhoogte, als een minimale en maximale gezichtsbreedte. Hoewel de bandbreedte van de verhoudingen van hoogte en breedte tussen minimaal 1,3 en maximaal bijna 1,9 ligt, en daarmee vrij ruim lijkt, blijkt bij nader onderzoek 2,7 procent van de volwassen Nederlanders, oftewel meer dan 378 duizend personen van 14 jaar of ouder, niet daarbinnen te passen vanwege een buitensporig breed of juist lang gezicht. Een niet onaanzienlijk probleem dat voorkomen had kunnen worden wanneer men ook gevoel had gehad voor de betekenis van metingen en alleen eisen aan de pasfoto- en hoofdhoogte had gesteld. Met een knipoog kunnen we wel stellen dat het handhaven van onze strenge eisen het probleem van de dubbele paspoorten kleiner kan maken.

Terug naar spiegeling. Zien wij in de spiegel een perfecte weergave van onszelf? Eigenlijk niet. Want, hoewel wij in principe symmetrisch zijn opgebouwd, een eigenschap waar ik later nog in veel meer detail op terug zal komen, is ons gezicht niet helemaal gelijk aan de linker- en de rechter zijde. Vaak staat het ene oor iets hoger dan het andere, is de neus net uit het midden, hebben we een scheiding in het haar, hetgeen $u$ ook kunt opmerken in de portretstudie van da Vinci. 
Ik wil nu verder ingaan op asymmetrie in de natuur.Zonder overdrijven kan ik stellen dat ons bestaan is gebouwd op, door, en rondom asymmetrie. Telkens komt links- of rechtshandigheid, links- of rechtsdraaiend naar voren. Kijkt u maar eens naar moleculen van suikers of aminozuren, de kleinere bouwstenen van ons lichaam. Reeds door Pasteur was vastgesteld dat er twee vormen zijn van deze moleculen. Wanneer aan één en hetzelfde koolstofatoom 4 verschillende groepen zijn bevestigd, kan dat namelijk op 2 manieren. Oppervlakkig gezien heb je dan dezelfde moleculen, maar bij nadere inspectie zie je dat de 2 het spiegelbeeld zijn van elkaar. Er is chiraliteit, het Griekse woord voor tweehandigheid. Je hebt een linker en een rechter vorm. De moleculen zijn enantiomorfen. Hoewel $u$ misschien verwacht dat in de natuur gelijke hoeveelheden van de linker en de rechter vorm voorkomen, is dat niet het geval. Zo zijn aminozuren bijna exclusief linkshandig en zijn suikers overwegend rechtshandig. En had u zich gerealiseerd dat DNA, met zijn bekende helixstructuur, op aarde altijd een rechtshandige helix heeft?

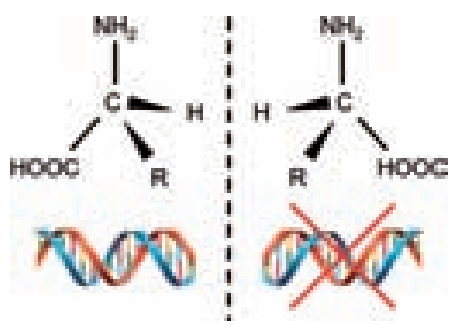

Figuur 11 Veel moleculen hebben een asymmetrische bouw zodat er een linkshandige en een rechtshandige vorm van kan bestaan. Aminozuren zijn bijna exclusief linkshandig en suikers zijn overwegend rechtshandig. DNA heeft op aarde altijd een rechtshandige helix.

Wanneer we overstappen naar de organismen die met deze bouwstenen gemaakt worden, dan bemerken we dat de eenvoudigste vorm, de eencellige, aan de buitenzijde gezien symmetrievlakken in alle richtingen heeft. Betrekken we echter de inhoud van de cel ook in de vraag of de cel symmetrisch is, dan kunnen we niet meer bevestigend antwoorden op deze vraag. Bij planten wordt de symmetrie al minder omdat er een duidelijk verschil zit tussen wortel en stam. Toch kun je ze nog min of meer als een kegel beschouwen, met meerdere symmetrievlakken in de lengteas. Echter, kronkelplanten, zogenaamde wingerds, hebben een helix. En dan is er plotseling geen symmetrie meer. Opvallend is dat de meeste wingerds een rechtshandige helix hebben. 


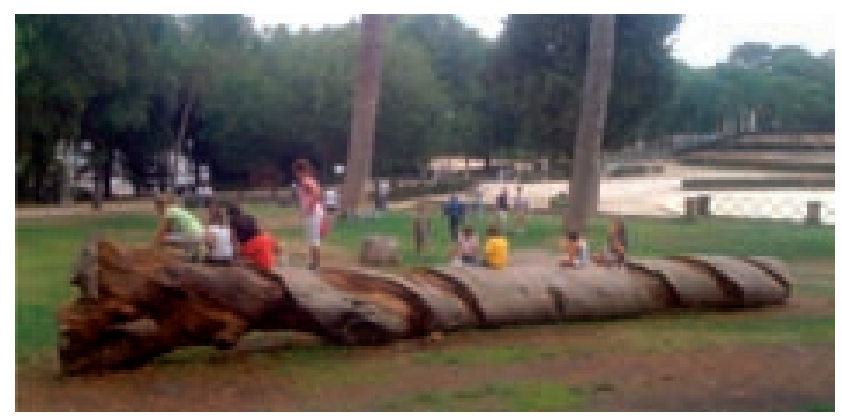

Figuur 12 Overtuigend rechtsdraaiende helixstructuur in de boomschors van een omgevallen boom in de Villa Borghese te Rome.

Ook in boomschors zit vaak een helixstructuur, die op deze dia overtuigend rechtsdraaiend is. En nee, ik heb deze foto niet gespiegeld, hetgeen $u$ kunt opmaken uit het feit dat de zichtbare horlogedragers allen hun horloge aan de linker pols dragen. Beesten die vastzitten, bv. anemonen, of die nauwelijks bewegen, zoals kwallen, hebben vaak een kegelsymmetrie. Gaan beesten echt bewegen, dan blijft er vaak maar één symmetrievlak over: kop en staart zijn verschillend, net als buik en rug. Links en rechts zijn echter elkaars spiegelbeeld, mogelijk omdat er geen voordeel is te behalen uit asymmetrie op dit niveau. Natuurlijk zijn hier uitzonderingen op, zoals blijkt bij de slakken met hun overduidelijk asymmetrische huisje: bijna alle species hebben uitsluitend een rechtshandige helix, er zijn er enkele met uitsluitend een linkshandige helix, en er zijn heel weinige, zoals de Amphidromus perversus, met zowel rechts- als linkshandige helices, waarvan ik $u$ hier twee exemplaren laat zien.

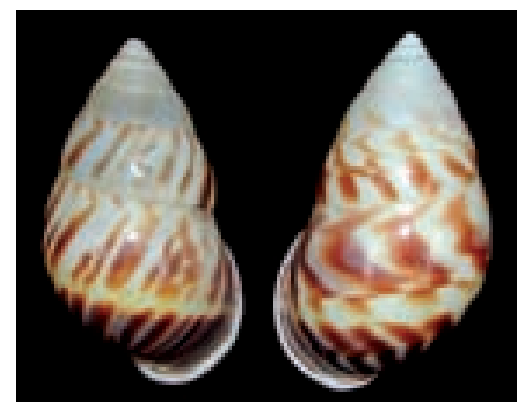

Figuur 13 Van de Amphidromus perversus bestaan zowel exemplaren met een rechtshandige als met een linkshandige helix. 
Zoogdieren en de mens zijn uiterlijk bijna symmetrisch, zoals we zagen toen we heel nauwkeurig naar het gezicht keken. Maar ook op een ander vlak is er wel degelijk uiterlijke asymmetrie. Dit was bij de Grieken en Romeinen al genoegzaam bekend, zoals ik onlangs weer bevestigd zag, toen ik de Musei Capitolini in Rome bezocht. Indachtig de IG Nobelprijs winnaar McManus heb ik de mannelijke naakten bekeken op de positie van hun testes. Het bleek inderdaad dat de klassieken wel notie hadden van deze asymmetrie, maar, in tegenstelling tot de huidige werkelijkheid met eigenlijk overwegend links lager gelegen testes, beelden zij bij $56 \%$ van de beelden een links lager gelegen testis uit, bij $23 \%$ een rechts lager gelegen testis, en bij $21 \%$ waren de testes op gelijke hoogte gelegen. Aangezien de Grieken en Romeinen nog niet van foto's, met het inherente gevaar van spiegeling, konden werken, ligt het verschil in verdeling van de positie van de testes ten opzichte van die van vandaag de dag daar in ieder geval niet aan.
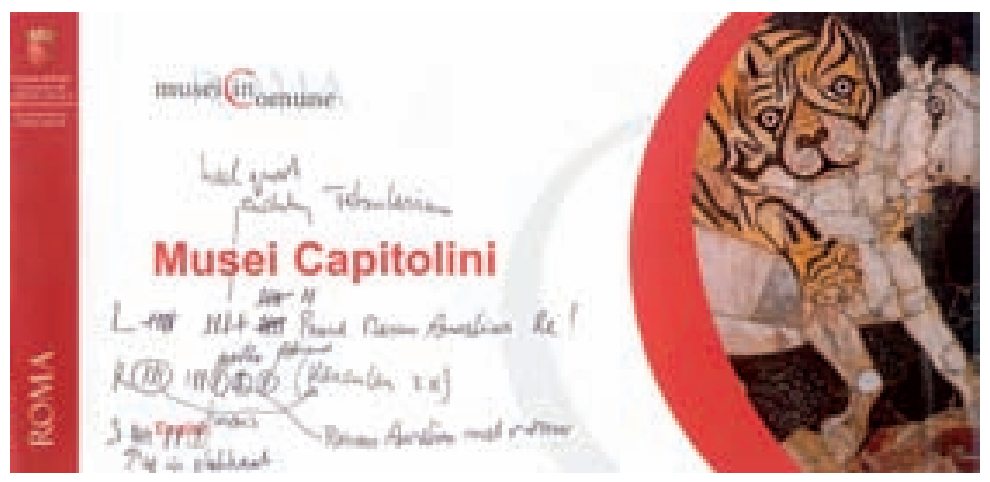

Figuur 14 De distributie van de positie van de testes in mannelijke naakten in de Musei Capitolini. $\mathrm{L}=$ linker testis is laagst, $\mathrm{R}=$ rechter testis is laagst, $\mathrm{S}=$ symmetrische positie van de testes.

Het schijnbaar symmetrische uiterlijk van gewervelden verbergt dramatisch grote inwendige links-rechts verschillen. Een kind weet al dat zijn of haar hartje links klopt, en ben je wat ouder, dan weet je ook wel dat je maag en milt links in je buik liggen, en dat je lever en je blindedarm aan de rechterkant van de buik gelegen zijn. De zojuist beschreven asymmetrie qua orgaanpositie wordt situs solitus genoemd en is aanwezig bij alle gewervelden die tot heden bestudeerd zijn. 
Ook Leonarda da Vinci was zich van deze inwendige asymmetrie bewust, zij het dat hij dan weer de linker, dan weer de rechter nier hoger afbeeldt en geen rekening houdt met de symmetrische ligging van adres en slagaders in de benen, dit laatste hoogstwaarschijnlijk omdat hij zich nog niet bewust was van de verschillende functie van deze vaten.
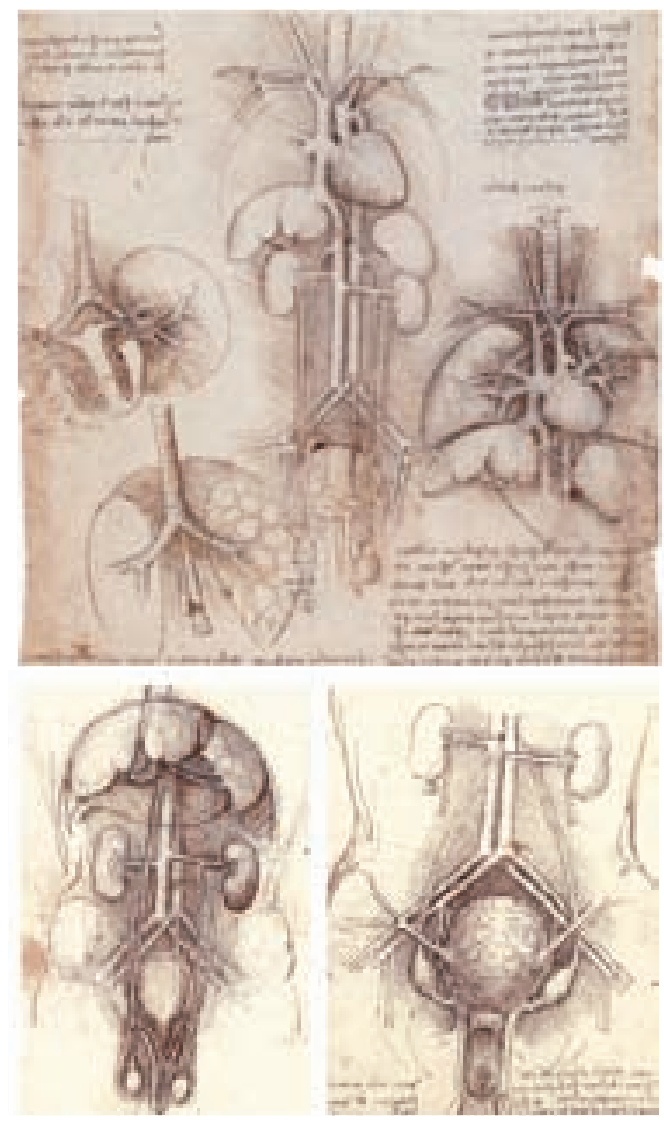

Figuur 15 De anatomie van borst en buik volgens Leonardo da Vinci waarbij afwisselend de linker en de rechter nier hoger afgebeeld wordt en er geen rekening wordt gehouden met de symmetrische ligging van adres en slagaders in de benen (boven: pen, twee tinten bruine tekeninkt en zwartkrijt, 283 x 219 mm, Windsor Castle, Royal Library (RL 19104v); linksonder: pen, bruine tekeninkt en zwartkrijt, $263 \times 189$ mm, Windsor Castle, Royal Library (RL 19099r); rechtsonder: pen en bruine tekeninkt, 192 x 135 mm, Weimar, Kunstsammlungen zu Weimar, Schlossmuseum, inv. KK 6287). 
Deze positie van organen hebben dokters dan ook als een soort archetype in hun hoofd zitten. En niet alleen dokters, getuige het verhaal van een 85 -jarige vrouw die, omdat zij van mijn wetenschappelijke interesse gehoord had, contact met mij had gezocht. Zij vertelde dat, toen zij na de $2^{\mathrm{e}}$ wereldoorlog met doorlichting op tuberculose werd gescreend, de dokter zei: 'Zuster, de patiënt staat verkeerd om'. De zuster antwoordde geïrriteerd dat dit absoluut niet het geval was, waarop de dokter reageerde met 'Maar dan zit bij haar het hart aan de andere kant'. Hierop zei mijn zegsvrouwe triomfantelijk: 'Ik zei het altijd al tegen mijn moeder dat mijn hartje rechts klopte, maar zij wilde dat nooit geloven'.
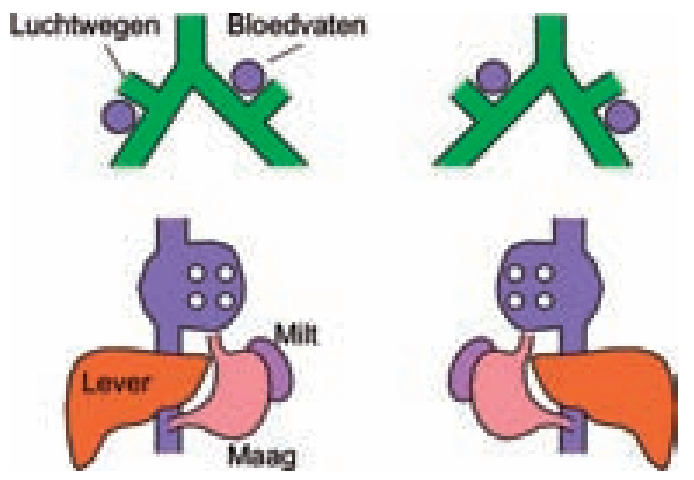

Figuur 16 Normale en gespiegelde ligging van borst/buikorganen.

Deze vrouw heeft een Situs Inversus Totalis, een kompleet gespiegelde positie van de organen. Dat zij nu nog steeds in goede gezondheid leeft is aan de ene kant tekenend voor de flexibiliteit van het menselijk leven en aan de andere kant zeer intrigerend omdat niet alleen het hart qua ligging gespiegeld is, maar ook qua uiterlijk, terwijl de feitelijk asymmetrische bouwstenen qua spiercellen, moleculen en DNA dezelfde zijn als in een persoon met normale positie van de organen. En hoe kunnen wij zo symmetrisch zijn gebouwd qua armen, benen, vaten en nieren, terwijl onze bouwstenen asymmetrisch zijn? Deze intrigerende vraagstukken vormen m.i. mooie voorbeelden waar Biomedische Technologie een rol kan spelen. Tevens zijn ze weer een mooi voorbeeld dat de afwijkingen van normaal ons waarschijnlijk veel meer kunnen leren over ons normale functioneren, dan het normale zelf. 
Het is tijd voor een kort divertimento op het gebied van muziek. Ook hier kan spiegeling optreden. Veel componisten hebben zich beziggehouden met spiegelduetten, een vorm waarbij de bladmuziek horizontaal tussen de spelers wordt gelegd: de ene muzikant ziet de noten normaal en de andere ziet de noten op de kop. Als voorbeeld toon ik $u$ 'Der Spiegel Duett für zwei Violinen' van Wolfgang Amadeus Mozart. Het betreft hier echter geen enkelvoudige spiegeling in het horizontale of verticale vlak. Nee, het betreft hier een rotatie, hetgeen een dubbele spiegeling is: spiegeling in het horizontale vlak wordt gevolgd of voorafgegaan door spiegeling in het verticale vlak.

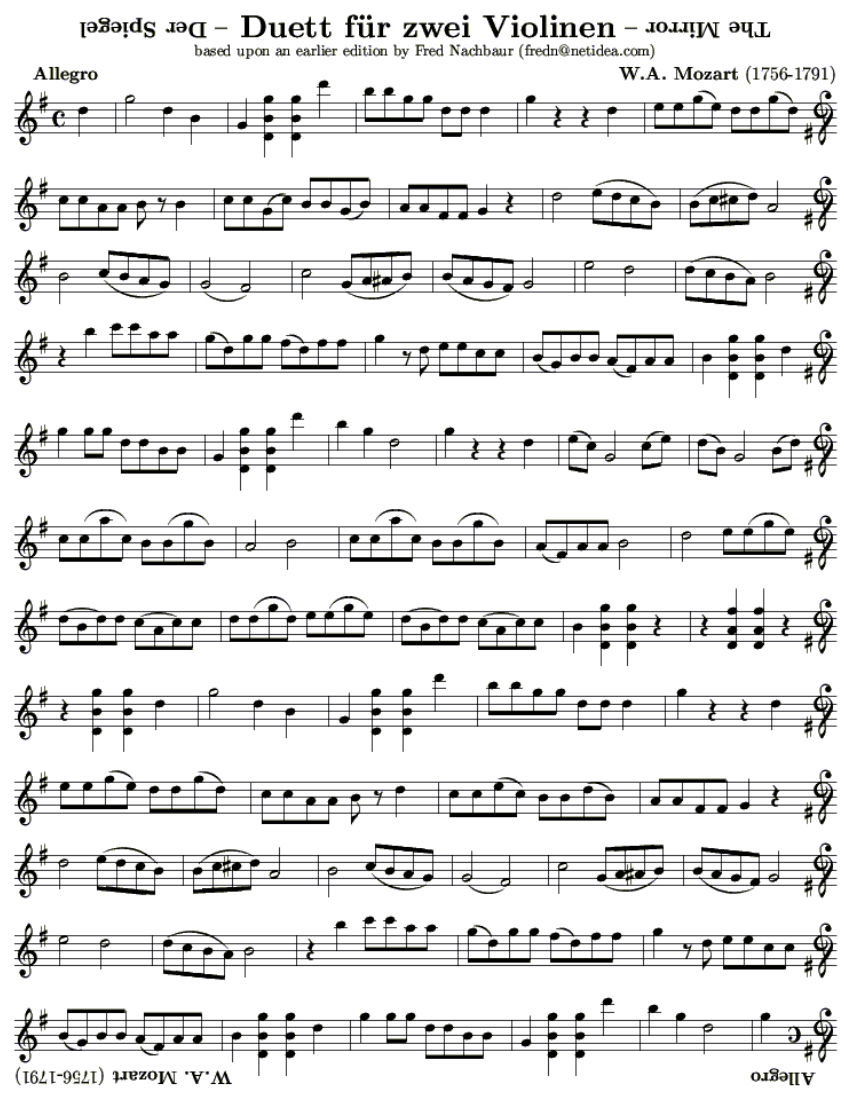

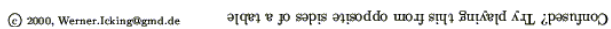

Figuur 17 Der Spiegel - Duett für zwei Violinen' van Wolfgang Amadeus Mozart. 
Wie wel muziek echt in één vlak spiegelt, verticaal of horizontaal, is Johann Sebastian Bach. Misschien had u zelf ook al aan Bach gedacht toen ik zei dat ik een fugatische rede wilde uitspreken, daar deze componist als de meester van de Fuga wordt beschouwd. Bach toont zich echt de grootmeester van het genre van de fuga in 'Das Musikalisches Opfer', BWV 1079. Het betreft hier een verzameling van canons en fuga's die geheel gebaseerd zijn op één muzikaal thema dat Bach was opgegeven door Koning Frederik de Grote van Pruisen. Bach heeft bij de uitwerking van het Koningsthema gebruik gemaakt van alle mogelijke compositorische technieken zoals inversie, modulatie en augmentatie. Canons werden in die tijd gezien als een speciaal geval van de fuga, nl. een fuga ligata, een gebonden fuga.

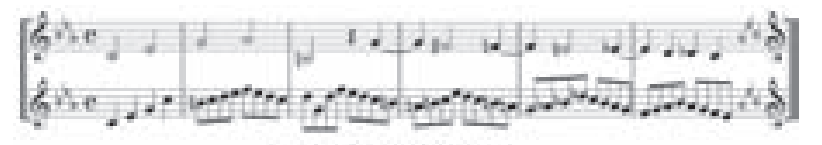

CRAB CANON FE

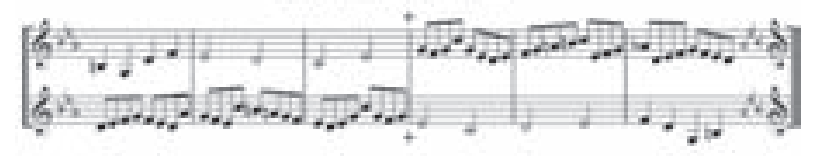

แ ИОИАつะАЯ

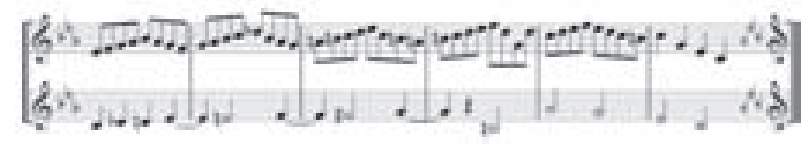

Figuur 18 Canon 1, a 2 cancrizans van Johann Sebastian Bach (Das Musikalisches Opfer BWV 1079).

De in mijn ogen mooiste canon wil ik $u$ niet onthouden (bekijk en beluister de video op http://strangepaths.com/canon-1-a-2/en/). In deze canon wordt in de eerste stem het gehele thema en het muzikale antwoord ten gehore gebracht. De tegenstem doet tegelijkertijd precies hetzelfde, maar in tegengestelde richting: deze stem begint bij de laatste noot van het antwoord en eindigt bij de eerste noot van het thema. De stemmen kruisen elkaar in het midden. Een dergelijke canon wordt kreeft-canon of, in het Engels, crab canon genoemd, omdat van de kreeft gezegd wordt dat je niet kunt onderscheiden of deze voor- of achteruit beweegt. Let op de perfecte mathematische aanpak van Bach, die ertoe leidt dat zijn muziek op een Moebiusband kan worden geschreven, zonder dat hij al van het bestaan van dit soort banden wist. 
We zijn aangeland bij de finale, ons onderzoek.

In zijn Tractatus de corde uit 1669, geeft Lower al uitgebreid aan dat het vezelpatroon van het hart een helix volgt. Het figuur linksonder trof $u$ destijds aan op het kaft van mijn proefschrift en het siert ook nu weer de uitnodigingskaart voor oratie en feest. Lower laat duidelijk zien dat het vezelverloop van het hart aan de buitenzijde een linkshandige helix heeft en aan de binnenzijde een rechtshandige. Aan de apex, dat is de punt van het hart, waarvan $u$ de afbeelding rechtsonder ziet, resulteert dit in een kloksgewijs draaiende vortex.

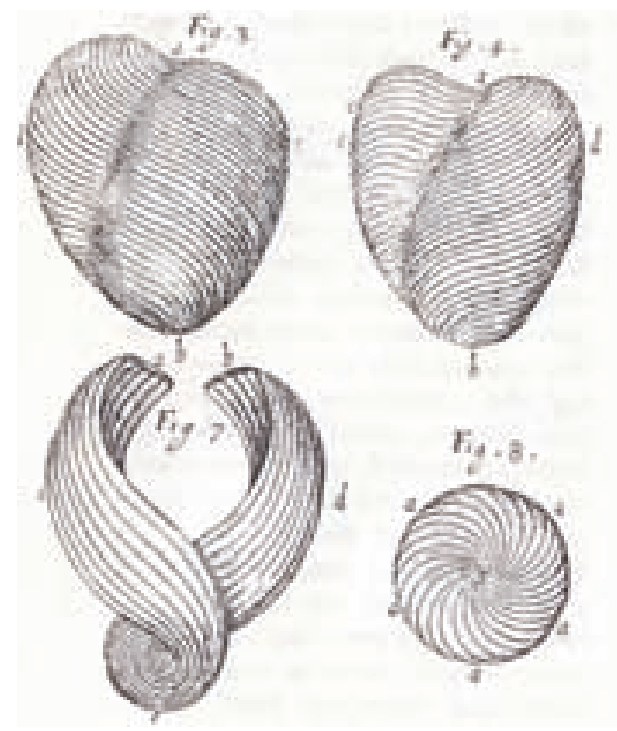

Figuur 19 Vezelpatronen in het hart volgens Lower (Lower R. Tractatus de corde. London; 1669).

In Maastricht houden wij ons al tijden bezig met de achtergrond van deze heel speciale bouw. Waarom heeft het hart deze ingewikkelde spiervezeloriëntatie, terwijl skeletspieren de vezels allemaal zo keurig parallel gerangschikt hebben, zoals $u$ mooi kunt zien in het lokale gerecht 'zuur vlees', met 'draadjesvlees'. Om dit te onderzoeken hebben we, in navolging van da Vinci, rekenkundige modellen gemaakt. In deze modellen proberen we altijd vanuit de fysiologie en de natuurkunde de eigenschappen van de basale bouwstenen van het hart te karakteriseren en te vatten in formules. Het betreft dan de eigenschappen van de 
spiercel (waarvan het kleinste samentrekkende deel de sarcomeer wordt genoemd), van de fibroblast (een bindweefselcel) en van het cement tussen de bouwstenen (de extra-cellulaire matrix). Ik geef $\mathrm{u}$ een niet uitputtende lijst van eigenschappen: de oriëntatie van spiervezels, de lengte van de sarcomeer bij het begin van samentrekken, de hoeveelheid en snelheid van verkorting, de maximale verkorting en rek, de spanning, de contractiliteit (hetgeen de kracht is waarmee samengetrokken wordt) en de stijfheid van de extra-cellulaire matrix.

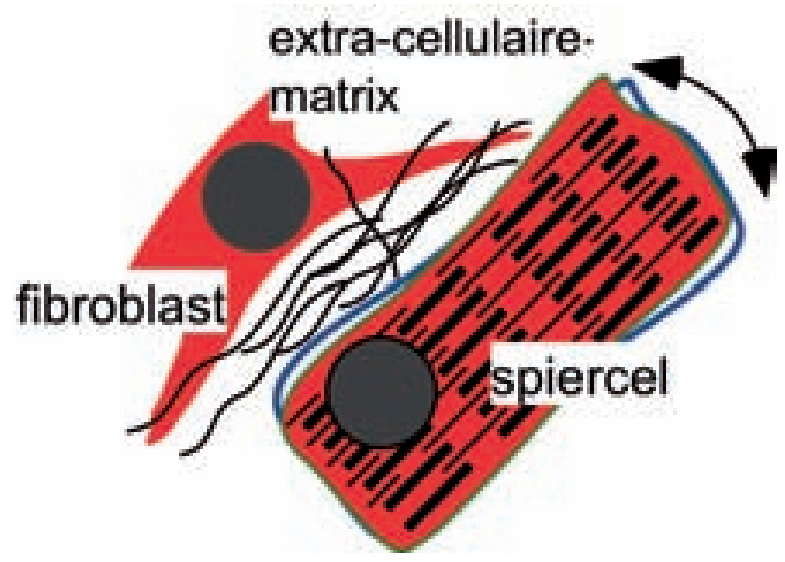

Figuur 20 De elementaire bouwstenen van het hart.

Ook wordt de globale bouw van het hart opgegeven aan het model. Vervolgens laten we het model rekenen en vergelijken we de resultaten qua spiervezeloriëntatie en -mechanica, en qua hartfunctie met experimenteel verkregen data. Op grond van die vergelijking passen we eventueel onze gehypothetiseerde karakteristieken aan. Het blijkt dat als je uitgaat van de aanname dat de basale bouwstenen zich overal hetzelfde gedragen, er een spiervezeloriëntatie in ons gesimuleerde hart ontstaat die overeen komt met de werkelijkheid. Waar je ook kijkt in het linker ventrikel, het verloop van de spiervezelrichting over de wand is overal hetzelfde: aan de buitenkant volgens een linkshandige helix, naar het midden van de wand langzaam veranderend in horizontaal lopende spiervezels, en naar de binnenkant veranderend richting een rechtshandige helix. Ook de door het hart opgebouwde druk en de hoeveelheid bloed die per hartslag uitgepompt wordt, zijn fysiologisch. Tevens zien wij dat het linker ventrikel tijdens het uitpompen een torsie 
vertoont, d.w.z. de punt van het hart draait de andere kant op dan de bovenkant van het hart. Echter, deze uitkomsten golden alleen voor het normaal gebouwde hart dat gelegen was aan de linkerkant. De vraag rees hoe dit zou zijn in het hart van personen met een Situs Inversus Totalis waarbij het hart gespiegeld is t.o.v. normaal. Daartoe wilde ik graag zo'n hart eens nader bekijken. Omdat deze variant op normaal slechts zelden voorkomt, zo'n 1 x op de 10.000 mensen, heb ik de keurmeesters in de slachthuizen gevraagd om uit te kijken naar varkens met een gespiegeld hart. Acht maanden later en zo'n kleine 10 miljoen dode varkens verder, kreeg ik het verlossende telefoontje: er was een gespiegeld varkenshart gevonden.
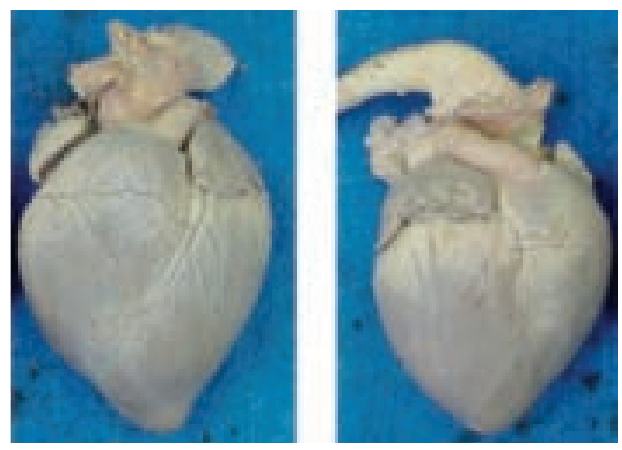

Figuur 21 Een normaal varkenshart (links) en het hart van een varken met gespiegelde orgaanpositie (rechts).

Zijn deze harten enantiomorfen van elkaar? Bij nader inspectie niet! Kijkt u maar naar het patroon van de hartslagaders. En toen we het hart gingen onderzoeken op de oriëntatie van de spiervezels bleek er iets heel vreemds aan de hand te zijn: er was geen compleet spiegelbeeld in dit patroon! En dan komen de zegeningen van internet naar voren: want geleid door onze bevinding gingen we op speurtocht en vonden een publicatie uit 1926 van één van de grondleggers van de Kindercardiologie, Dr. Helen B. Taussig. Zij had destijds ook al opgemerkt dat de spiervezeloriëntatie aan de buitenzijde van een gespiegeld hart net zo was als die van een normaal hart. In de diepere lagen van het gespiegelde hart zag zij echter wel een abrupte overgang naar een gespiegelde spiervezeloriëntatie. In het varkenshart, dat wij veel nauwkeuriger konden onderzoeken door gebruik te maken van de MRI, zagen wij dat de bovenkant van het hart wel een gespiegeld patroon had qua spiervezeloriëntatie, maar dat de punt van het hart een normaal patroon had. 


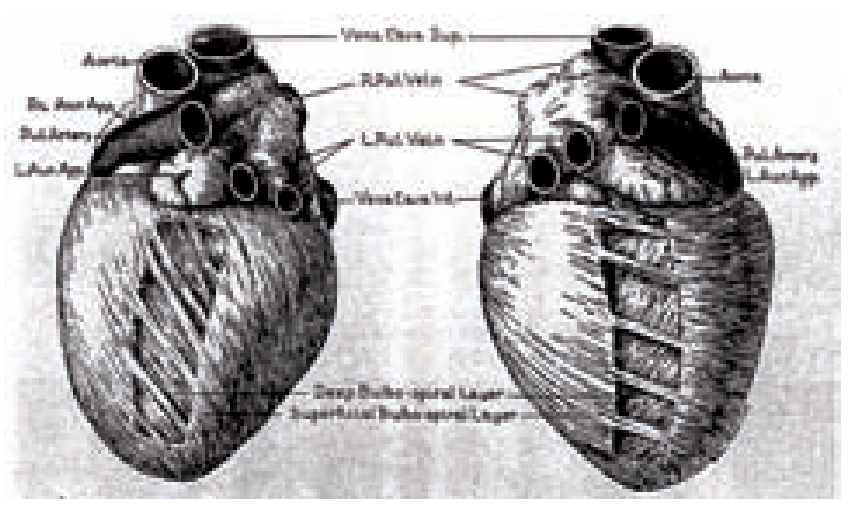

Figuur 22 Spiervezeloriëntaties volgens Dr. Helen B. Taussig in een normaal (links) en een gespiegeld menselijk hart (rechts; H.B. Taussig (1926) Bull. Johns Hopkins Hosp. 39: 199-202).

Als ik het hart zou weergeven als een huis en de spiervezeloriëntatie als de deur in dat huis, dan is er dus wel een compleet gespiegeld huis qua vorm, maar is er iets aan de hand met de deur. De deur gaat verschillend open aan de boven- en de onderzijde. Dit zal in het dagelijks leven tot problemen kunnen leiden.

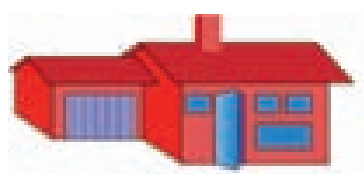

Normaal harthuis

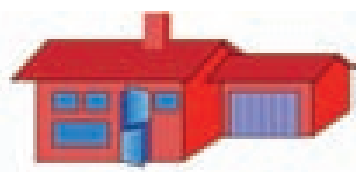

Gespiegeld harthuis

Figuur 23 Een normaal en een gespiegeld harthuis, waarbij de deur de spiervezeloriëntatie weergeeft. In het gespiegelde harthuis gaat de deur verschillend open aan de boven- en de onderzijde.

Hoe kan het nu, zo vroegen en vragen we ons nog steeds af, dat de duale structuur voor het gespiegelde hart geen beperking vormt. Tevens proberen we antwoord te krijgen op de vraag wat de oorzaak is van deze duale structuur: zou je het kunnen verklaren uit de functie van de asymmetrische bouwstenen? Ook houden we ons bezig met de opbouw van slagaders en de afvoerbuizen uit de nieren, die, omdat ze hoge drukken moeten kunnen weerstaan, ook veel spiercellen hebben. Is bv. de slagader in de linker lies qua bouw een enantiomorf van de rechter, en zo ja, hoe kan dat, want ze komen beide uit de aorta. Of is er een symmetrische structuur. Veel vragen en een m.i. dankbaar onderzoeksveld. 

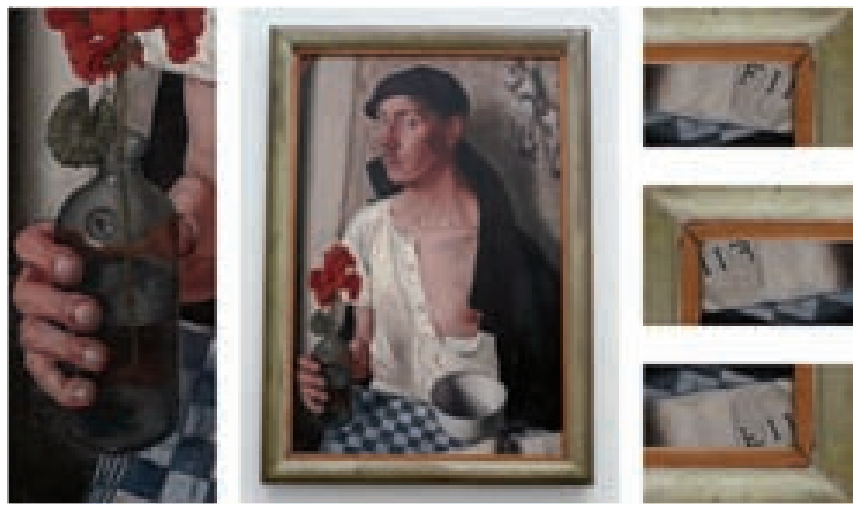

Figuur 24 Een dubbele spiegeling in de beeldende kunst (Dick Ket (10 oktober $1902-15$ september 1940), zelfportret uit 1932).

In een laatste divertimento, nu op het gebied van de beeldende kunst wil ik met $u$ een synthese maken van al het tot nu toe naar voren gebrachte. Ik kies hierbij de afbeelding van een schilderij van Dick Ket. Laten we nu eens als een echte Leonardo da Vinci dit beeld tot ons komen. Het betreft hier een zelfportret van de schilder. Met het oog van de Kindercardioloog gaan we een lichamelijk onderzoek verrichten. Bij nadere inspectie blijkt dat de vingertoppen afwijkend zijn. De nagels zijn blauw verkleurd en de toppen zijn verdikt. Het betreft hier zogenaamde trommelstokvingers, symptoom van o.a. hartafwijkingen waarbij er te weinig zuurstof in het bloed zit. Dankzij het beeld rechtsonder kunnen we afleiden dat het een zelfportret in een spiegel betreft. Als we het beeld rechtsonder vergroten, zien we dat hier een woord op de kop staat. Na roteren bemerken we dat het een woord in spiegelbeeld is. Spiegelen we deze afbeelding, dan blijkt er FIN te staan, een mogelijke aanduiding voor het nakende einde van het leven van de kunstenaar ten gevolge van zijn hartafwijking. Als we nu deze door ons ontdekte gegevens combineren en in het achterhoofd houden dat Ket altijd zeer symbolisch te werk ging, dan duidt het feit dat Ket zijn rechterborst heeft ontbloot er waarschijnlijk op dat zijn hart hier gelegen was. Dick Ket heeft een aangeboren blauwe hartafwijking met in ieder geval een Situs Inversus van zijn hart, een zogenaamde Dextrocardie. Vandaar dat ik de dia de titel 'Een dubbele spiegeling in de beeldende kunst' meegaf. Dit speuren, deze synthese van kennis en ervaring, is wat m.i. in onderzoek, opleiding en patiëntenzorg dient plaats te vinden. Een goed clinicus is als een schaker die enerzijds veel patronen uit zijn hoofd moet kennen en anderzijds creatief moet kunnen denken en nieuwe situaties het hoofd kunnen bieden. 


\section{Dankwoord}

Gekomen aan het einde van mijn les wil ik nog een dankwoord uitspreken. De Rector Magnificus, de leden van het College van Bestuur, de decanen van zowel de faculteit Health, Medicine and Life Sciences van de Universiteit Maastricht, als van de faculteit Biomedische Technologie van de Technische Universiteit Eindhoven, en alle overigen die aan mijn benoeming hebben meegewerkt, wil ik bedanken voor het vertrouwen mij gegeven.

Hooggeleerde Reneman, beste Rob, wat ben ik blij dat ik jou als leermeester en promotor heb gehad. Ik vond het moeilijk om aan het eind van mijn promotieperiode je kenbaar te maken dat ik niet in het onderzoek wilde blijven, maar dat ik Kinderarts en uiteindelijk Kindercardioloog wilde worden. Van jouw reactie heb ik toen veel geleerd. Je bezag de feiten, analyseerde die, trok je plan, en hielp mij voorwaarts richting een opleidingsplaats Kindergeneeskunde. Daarbij merkte je wel tussen neus en lippen door op dat ik 'nog niet verloren was' omdat ik onderzoek toch veel te leuk vond. De dag van vandaag bewijst maar eens te meer hoe vaak je gelijk hebt. Ik ben je echter nog meer dankbaar dat jij niet alleen een begeleider op de werkvloer bent, maar dat je, met je lieve vrouw Wijnanda, altijd weer klaar staat wanneer ik een handje extra nodig heb op het persoonlijke vlak. Samen met jullie kinderen en kleinkinderen geven jullie mij echt het gevoel dat ik hier, in het vanuit het Noorden gezien verre Zuiden, familie heb waar ik altijd terecht kan.

Hooggeleerde Arts, beste Theo. Ook jij speelt, samen met Jacqueline, een grote rol in mijn leven. Altijd maar weer discussiëren we over de gekste onderwerpen. Ik zal nooit weer het moment vergeten dat uiteindelijk geleid heeft tot het onderzoeksgebied van de gespiegelde mens. Ik beweerde dat bij een hartafwijking waarbij de functie van de linker en rechter kamer is omgewisseld, de scheidingswand tussen de kamers niet meer goed kan functioneren, omdat deze wand dan in spiegelbeeld moet werken. Geleid door je ruimtelijk inzicht ontkende jij dit echter direct. Jij maakte je standpunt duidelijk door een aantal viltstiftstrepen op een plastic bekertje. Ik kreeg een 'Eureka-moment' en zei: 'Maar bij een Situs Inversus Totalis moet je wel een gespiegeld vezelrichtingspatroon hebben.' Echter, zoals uit mijn rede is gebleken, ook deze keer had ik het niet bij het juiste eind. 
Hooggeleerde Prinzen, beste Frits. Samen met Mieke ben jij ook niet uit mijn leven te denken. Jij schuwt het experiment niet, komt altijd weer met mooie associaties en hebt een tomeloze energie. Ik heb nu de vakgroep Fysiologie verlaten, maar ben blij dat ik in jou een maatje heb als het gaat om onderzoek op het gebied van de mechanica en pompfunctie van het hart.

De hooggeleerden Zijlstra en Mook wil ik bedanken voor het begeleiden van mijn eerste schreden op het gebied van onderzoek van het hart ten tijde van mijn studie Geneeskunde in Groningen.

De hooggeleerden Blanco, Donckerwolcke en Zimmermann ben ik dankbaar dat zij, als opeenvolgend voorzitter van de vakgroep Kindergeneeskunde, mij altijd de ruimte hebben gegeven om als Kindercardioloog werkzaam te blijven op het gebied van de basale wetenschap.

De hooggeleerden Allessie en Post hebben als voorzitter van de vakgroep Fysiologie het juist altijd weer geaccepteerd, nee zelfs gestimuleerd, dat ik ook clinicus bleef.

Alle medewerkers van de vakgroepen Kindergeneeskunde en Fysiologie wil ik bedanken voor het feit dat zij altijd weer die andere kant van mij accepteerden.

Alle medewerkers van de vakgroep Biomedische Technologie wil ik bedanken voor de enorm prettige sfeer die direct ontstond nadat de drie bloedgroepen uit respectievelijk het academisch ziekenhuis Maastricht, de Technische Universiteit Eindhoven en de Universiteit Maastricht waren samengevoegd. Het is daardoor een plezier om naar het werk te gaan, hetgeen ik dan ook letterlijk al fluitend en zingend doe.

Allen hier aanwezig wil ik bedanken voor de belangstelling. Velen, met name vrienden en familieleden, waarbij ik speciaal mijn ouders wil noemen, zijn van verre gekomen. Door uw komst hebt u deze dag extra feestelijk gemaakt. 
Lieve Lodewijk, Rutger en Pauwel, wat ben ik trots op jullie en wat leer ik veel van jullie. Lieve Annelies, samen met de jongens houd jij mij altijd weer een spiegel voor. En alleen door voortdurende reflectie kunnen we het leven mooi houden.

Ik dank u allen voor uw aandacht,

Ik heb gezegd.

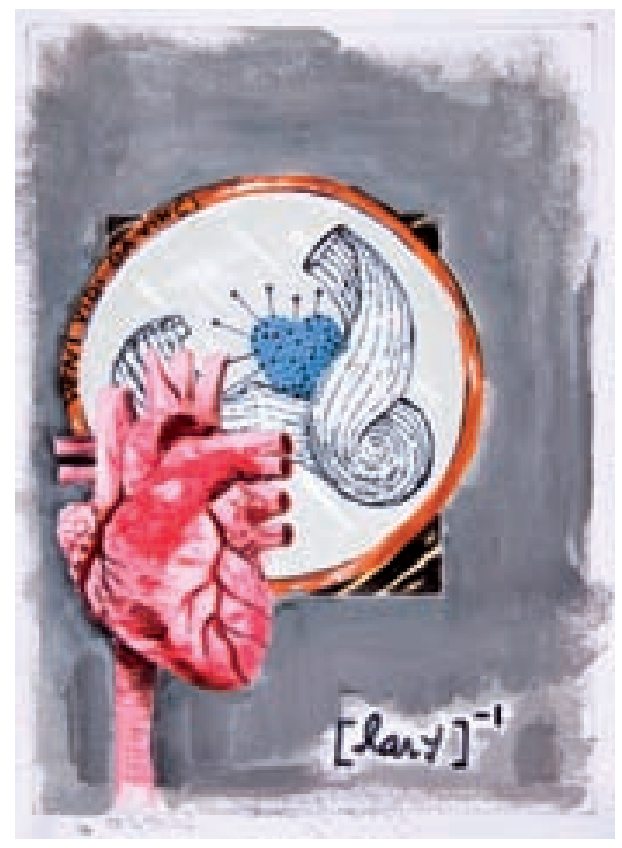




\section{Bibliografie}

Calder R. Het speurend oog van Leonardo. 1e druk. Amsterdam, H. J. W. Becht's Uitgeversmaatschappij N.V. ISBN 9023001451.

Capra F (2008). De Wetenschap van Leonardo da Vinci. Eerste druk. Utrecht, Uitgeverij het Spectrum. ISBN 978902749861.

Coren S (1993). The left-hander syndrome: the causes and consequences of lefthandedness. First Vintage Books edition, July 1993. New York, Random House, Inc. ISBN o 679744681.

Daanen HAM, Krul AJ, Ball R (2010). Face dimension and passports requirements. Journal of BTHA XV: 53-56.

Dijksterhuis EJ (1985). De mechanisering van het wereldbeeld. Vijfde druk. Amsterdam, Meulenhoff. ISBN 9029015705.

Gardner M (2005). The new ambidextrous universe: symmetry and asymmetry from mirror reflections to superstrings. Rev. ed. Mineola, N.Y., Dover Publications, Inc. ISBN 0486442446.

Hofstadter DR (1985). Gödel, Escher, Bach: een eeuwige gouden band. Amsterdam, Uitgeverij Contact. ISBN 9025466532.

Höweler C (1957). Inleiding tot de muziekgeschiedenis. Zesde, grondig herziene druk. Amsterdam, H.J. Paris.

Jeram A (2001). Muisje Andersom. Rotterdam, Lemniscaat b.v. ISBN 9074336663. Lewis C (1871). Through the Looking-Glass, and What Alice Found There. London, MacMilan.

Lower R (1669). Tractatus de corde. London.

McManus C (2002). Right hand, left hand: the origins of asymmetry in brains, bodies, atoms, and cultures. London, UK, Weidenfeld \& Nicolson, Ltd. ISBN o 674009533.

Minnaert M (1974). De natuurkunde van 't vrije veld. 6e. Zutphen, B.V. W. J. Thieme \& Cie. ISBN 900390780.

Noble D (2006). The music of life: beyond the genome. Oxford, Oxford University Press. ISBN o 199295735.

Suh AH (2005). Leonardo's Notebooks. First trade paperback edition 2009. New York, Black Dog \& Leventhal Publishers, Inc. ISBN 9781579128173.

van Calmthout M (2010). Niet elke Nederlander heeft een gezicht dat op het paspoort past. de Volkskrant (5 november 2010, p5). Amsterdam, Persgroep Nederland.

Zöllner F (2007). Leonardo da Vinci: The complete paintings and drawings. Köln, Taschen GmbH. ISBN 9783822817346. 